This item was submitted to Loughborough's Research Repository by the author.

Items in Figshare are protected by copyright, with all rights reserved, unless otherwise indicated.

The value of the banker-customer relationship: experience of individual voluntary arrangements

PLEASE CITE THE PUBLISHED VERSION

PUBLISHER

(C) Palgrave Macmillan

LICENCE

CC BY-NC-ND 4.0

REPOSITORY RECORD

Pond, Keith. 2019. "The Value of the Banker-customer Relationship: Experience of Individual Voluntary Arrangements". figshare. https://hdl.handle.net/2134/1216. 
This item was submitted to Loughborough's Institutional Repository by the author and is made available under the following Creative Commons Licence conditions.

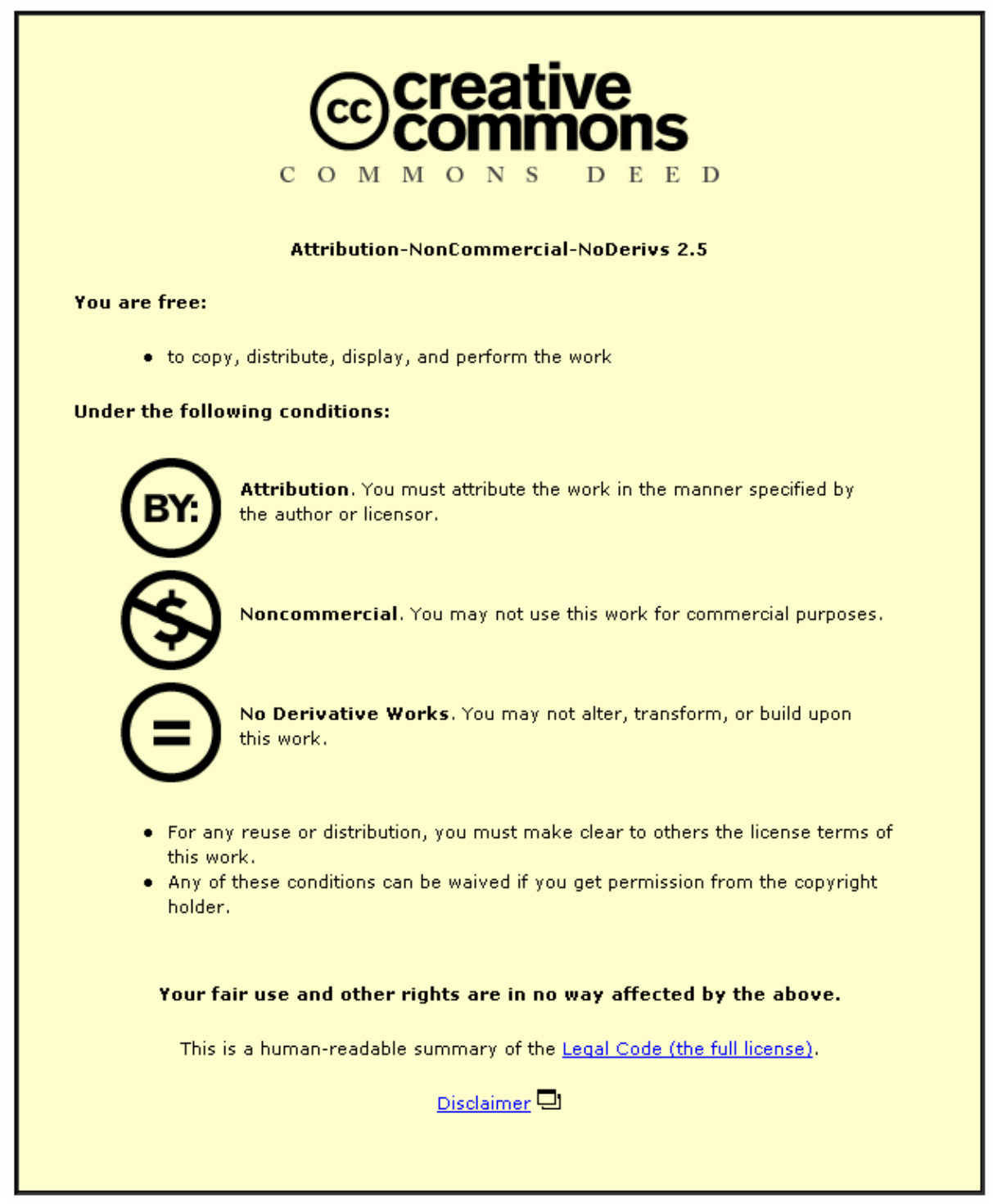

For the full text of this licence, please go to: http://creativecommons.org/licenses/by-nc-nd/2.5/ 


\section{Loughborough University}

\section{THE VALUE OF THE BANKER-CUSTOMER \\ RELATIONSHIP: EXPERIENCE OF INDIVIDUAL VOLUNTARY ARRANGEMENTS}

Keith Pond

The Banking Centre

Loughborough University

LOUGHBOROUGH

Leics.

LE11 3TU

Tel: $\quad 10509223290$

Fax: $\quad 01509223962$

E.Mail: K.Pond@lboro.ac.uk 


\title{
THE VALUE OF THE BANKER-CUSTOMER RELATIONSHIP: EXPERIENCE OF INDIVIDUAL VOLUNTARY ARRANGEMENTS
}

\begin{abstract}
Over the last ten to fifteen years, and in response to the huge growth in demand for unsecured consumer credit, UK banks have reviewed, automated, de-skilled and streamlined traditional credit assessment techniques. In pursuit of margin and market share, today's due diligence relies increasingly on centralised data and statistical “certainty".

During this same period the nature of the banks' "safety net", the sanction of bankruptcy and court action, has changed too. The effect of this is not only to increase the potential for recovery, in respect of bad debts, but also to increase the moral hazard problem. However, increased risk is masked by creditor power in recovery situations.

This paper draws on theoretical and empirical research from legal, ethical and economic viewpoints and suggests that a reappraisal of this aspect of the bankercustomer relationship is essential to restore trust, prudence and long-term profitability.
\end{abstract}




\section{THE VALUE OF THE BANKER-CUSTOMER RELATIONSHIP: EXPERIENCE OF INDIVIDUAL VOLUNTARY}

ARRANGEMENTS

\section{Introduction}

The relationship between a banker and a customer has its foundations in wellestablished UK case law ${ }^{1}$, reinforced, since 1992, by a code of conduct. Until 1997, however, the code was silent on the matter of dealing with non-performing loans. In 1997 banks made a firm commitment to

“consider cases of financial difficulty sympathetically and positively”.

Banks also pledged themselves to

“ help you (sic) to overcome your difficulties". ${ }^{2}$

The banks' commitment covers the period before formal insolvency action and also echoes a much-ignored plea from lenders for customers to give early warning of debt problems. Amongst the motivations for making this plea is that problems can be averted and a customer retained. Coincidentally, early warning of problems allows lenders to act to their own best advantage by taking individual action for debt recovery before the competing claims of other lenders level the "playing field” with the collective nature of the bankruptcy procedure. 
The code is silent, however, on the banks' treatment of customers following notice of formal insolvency. At these times there is growing evidence that banks act purely in their own short-term interests ${ }^{3}$.

This paper focuses on the law and practice surrounding personal and unincorporated business debt, although parallels in the corporate world are evident. The paper looks closely at the banker - customer relationship at a crucial time of crisis (customer insolvency) and surveys the various influences placed on bankers including the increasing demand for consumer credit and society’s changing attitude to bankruptcy.

The paper also looks at the statutory choices faced by insolvent debtors and their creditors and goes on to review the general economic factors that have coloured creditor behaviour during the last decade. It touches on the operational handling of insolvency situations, the creditors' policies towards problem debt and the ethical considerations that guide them.

The paper concludes by arguing that in a highly competitive environment, where debt is a direct corollary to credit granting, banks can do much to regain the trust and security that lead to profitable lifetime relationships with customers.

\section{The banker - customer relationship}

UK retail banks operate in an extremely competitive environment and invest heavily in gaining competitive advantage. Traditional banks suffer pressure on profit margins 
and growing threats from non-traditional competitors such as supermarkets and even football clubs ${ }^{4}$. Competitive pressures and available technology have, in part, resulted in an orientation away from the relational banking of the "old fashioned" high street bank manager, towards the standardisation and transactional banking of the direct seller. Technical competence in lending is largely subordinated to systematic "credit scoring” and centralisation based on empirical information from a variety of sources ${ }^{5}$.

Whilst streamlined systems for lending can reduce costs and increase profitability in the short-term it does serve to reinforce the moral hazard problems associated with dealing with borrowers at “arms length”.

The legal relationship between bankers and their customers was investigated by the National Consumer Council in $1983^{6}$ and reviewed by the Jack Committee, which reported in $1989^{7}$. Jack found that the legal relationship was robust and did not require urgent amendment ${ }^{8}$. Both the NCC and Jack, however, were silent on the specific problem of non-performing loans and bad debts.

With a widely publicised code of conduct in place, bankers and their customers should be more certain about their legal relationship. Their commercial relationship, however, is far less clear especially as both retail banks and consumers have undergone significant changes in recent years. Emphasis in the banker-customer relationship, bank training and professional education, has typically focussed on "beginnings" (the initial lending decision) and "endings" (the effective use of security). Whilst these are undoubtedly important it is the "middle" (the quality of relationship) that must now be developed. 
The emphasis on product based, transactional banking in the 1980's and early 90's had a marked effect on bank organisational structures and sources of income. Banks enjoyed the benefits of profitability and sales growth but suffered from a lack of customer loyalty ${ }^{9}$. Increased levels of competition and the advent of technology driven delivery channels have effectively compounded the problem by commoditising bank products and replacing inertia with a greater degree of customer empowerment.

Consequently, by the mid 1990's banks had begun to realise the importance of reintroducing “relationship management” and introducing customer retention policies. Although attitudes and practices are often slow to change in large organisations banks are beginning to balance the "lifetime value" of customers with the move towards individual account profitability ${ }^{10}$. Banks also know that customer acquisition is more expensive than customer retention although few have applied this logic of this in dealing with bad debts, insolvency and defaulting customers ${ }^{11}$.

US research has indicated that the long term success of firms, in terms of sustainable competitive advantage, is associated with investment in relationships with customers and suppliers $^{12}$ (in banking, customers and suppliers are synonymous in certain circumstances since funds deposited in accounts are used by banks to fund lending). Fine tuning of communications with customers also gives benefits. Specialised training and the focused deployment of staff can, therefore, help to engender the trust, satisfaction and commitment that banks desire in their relationships with customers ${ }^{13}$. 


\section{Insolvency Law and Practice}

Since passage of the 1986 Insolvency Act insolvent UK personal debtors have had access to a statutory Individual Voluntary Arrangement (IVA) procedure which is designed to avoid the finality and penalties of bankruptcy. The IVA between debtors and creditors was designed to allow viable sole traders to continue in business or to achieve a better and more orderly realisation of assets for the creditors. The legislative provisions followed the recommendations of a review committee ${ }^{14}$ and extensive consultation ${ }^{15}$ that noted the need to "rescue" debtors and to distinguish between the dishonest and the unlucky. Although the review committee also recommended a curtailed procedure for consumer debtors this was not carried through to the statute books and so the IVA "rescue" vehicle remains available to small unincorporated businesses and individual debtors alike.

The IVA is a private contract for the satisfaction of personal debts. As such it can be influenced by the quality of the relationships between lenders and debtors. In this court-supervised procedure the debtor proposes how the debts are to be satisfied, under the guidance of a licensed insolvency practitioner (IP) and under the protection of a "moratorium" on creditor action. The creditors are given the opportunity of amending and accepting or rejecting the proposal ${ }^{16}$.

Whilst bankruptcy ends the banker - customer contract the IVA does not. Consequently, creditor predisposition, influence and action have had an important place in the IVA procedure and the years since 1986 have seen a steady rise in the incidence and acceptance of IVAs ${ }^{17}$. There is also growing evidence of their 
successful application ${ }^{18}$. At the time of writing around $25 \%$ of formal personal insolvencies are dealt with via IVAs.

The choice faced by an increasing number of insolvent debtors is between IVA, and the avoidance of penalties, restrictions and opprobrium connected with bankruptcy or bankruptcy itself (liquidation of available assets). The choice faced by the creditor is limited by the predisposition of the debtor towards bankruptcy in the first instance and by the existence of "moral hazard" which makes the IVA riskier for the creditor. However, a successful IVA can improve creditor recoveries and increase customer retention, since income from continued employment or trade is often included as a benefit.

Moral hazard exists in the IVA situation because the creditor is forced by the Insolvency Act 1986 to make a choice between IVA acceptance and bankruptcy. If the creditors choose IVA, debtors can take actions, unobservable by creditors, which transfer greater risk to creditors. This is compounded by the lack of a formal investigation of the debtor's affairs in an IVA and the debtor's retention and possession of assets. Creditors must be aware that over-ambitious repayment proposals made by debtors may look attractive initially but may fail to materialise as debtors fail to co-operate with the IP once the IVA has been accepted. Creditors who doubt the integrity of the debtor or the IP can choose bankruptcy and the possibility of a public examination of the bankrupt in open court.

Creditor experience of bankruptcy is rarely good as official costs and the preferential treatment of some Crown debts deplete available assets and average returns from 
bankrupt estates are low ${ }^{19}$. This contrasts with the overall experience of IVAs ${ }^{20}$. For banks and larger lenders, with wider portfolios of debtors, successful IVAs are balanced against those that fail during their agreed term and return nothing. In this way larger creditors are more likely to favour IVA acceptance since their overall experience is positive. Smaller creditors, with their less extensive experience, may have more dichotomised views.

The asymmetric bargaining power of larger creditors, a result of their corporate experience, centralisation and specialisation, security position and size of debt and their increasing use of professional "meeting services", offered by Insolvency Practitioners, also helps banks, in particular, to influence the acceptance of IVAs more readily.

Generally, larger creditors are able to use their experience and select only IVAs that have a realistic chance of returning better dividends than bankruptcy. In these cases, their recoveries will be greater and, arguably, their retention of customers more marked.

\section{Economic considerations}

The fact that banks, as lenders, should be able to pursue profitable lending opportunities is not in question. What is questioned, however, is the time-scale over which such profits are measured. 
In the short-term it appears that banks have profited enormously from the unprecedented demand for unsecured consumer credit. Annual growth rates in credit card debt, for example, calculated as part of the money supply - M4, consistently exceeded RPI inflation by 2 to 3 percentage points between 1996 and $1998^{21}$. Over the same period bankruptcy and IVA numbers have grown (See Figure 1) and are now maintained at a higher level (total estimated at 28,000 for 1999) than at any time since the recession of the early 1990’s. In 1998-99 total insolvency growth outstripped the growth in consumer credit with IVAs maintaining their "share" of cases. Petitions for bankruptcy also maintained high numbers, with around $65-68 \%$ of all petitions being granted and debtors being made bankrupt between 1991 and $1998^{22}$

\section{TAKE IN FIGURE 1 ABOUT HERE}

Where banks hold unsecured debt the tendency in corporate insolvency has been towards liquidation (bankruptcy) rather than rescue or rehabilitation. Smaller businesses appear not to warrant bank involvement in workouts ${ }^{23}$ and the same policy appears to be adopted for unincorporated businesses and personal debtors. This approach is typically justified by banks on the basis that there is no point "putting good money after bad” (sic) ${ }^{24}$.

The financial argument for this is clear: the amount of debt written off (debt less recoveries) can influence specific provisions for bad and doubtful debt, net profits and tax charges. Transaction costs incurred in account intervention will merely add to losses in the short-term. 
The longer-term economic argument is less clear but sees write-offs as "sunk costs". Normal costs of extending credit must take potential losses into consideration and be discounted in the risk related interest rate charged. The decision to invest in relationships with debtors should not, therefore, take the bad debt loss into account. Instead, the decision should compare the risk weighted "lifetime value" of the debtor against the cost of a more detailed investment in customer rehabilitation.

In a congested and competitive market such a policy may be more commercially viable in the longer term, especially where both legislation and social values want to encourage "serial entrepreneurs”25 and where large numbers of bankrupts are repaying nothing to their lenders. Taking a slightly different perspective, customer information relating to crisis and rehabilitation could eventually lead to danger signals being recognised much earlier in the day, allowing banks to take preventative action and, perhaps, even avoid the need for bankruptcy and IVAs.

\section{The ethical dimension}

In 1984 Cork $^{26}$ recognised that changes in commercial life and society since passage of the Bankruptcy Act 1883 necessitated a review and refashioning of insolvency law. The 1986 reforms that Cork influenced recognised that there needed to be a balance between two separate views of bankruptcy: as a sanction against deviancy and consumer laxness (deterrence) and as a form of consumer protection ${ }^{27}$.

In a society based on credit, bankruptcy will still exclude individuals from the credit system and act as a punishment. It will also provide a "safety valve”, recognising that 
credit providers share responsibility for over-commitment. The key task in achieving this balance is to distinguish between the dishonest insolvent and the merely unlucky.

The main actors in achieving this balance, apart from individual debtors and creditors themselves, are Insolvency Practitioners and their public sector counterparts the Official Receivers. Cork's ${ }^{28}$ recommendation of a licensing system for IPs and the professionalisation of the industry coincided with the government's wish to reduce public sector involvement in the administration of bankruptcy. After 1986 The Insolvency Service, an Executive Agency of the DTI, wanted to concentrate on fraud and malpractice investigations. The strategy was to offer bankruptcy cases to the private IPs but the sheer numbers of bankruptcies that failed even to pay their own costs meant that by 1999 Official Receivers were involved in the administration of up to $50 \%$ of all insolvencies ${ }^{29}$.

The attendant pressure on Insolvency Service resources has a damaging effect on the perception of the efficient administration of estates. Although all bankrupts are subject to an investigation this may be paper based only, with much reliance placed on the debtor to provide information. This may be a factor that adds to the attraction of bankruptcy for the dishonest debtor.

Although no specific UK research has been undertaken into attitudes to bankruptcy there exist a number of other factors that help to shed light onto the conflicting attitudes to bankruptcy of creditors and debtors. Factors exist that support the deterrence view of bankruptcy law, typically held by creditors, and the rehabilitation view, presumably favoured by debtors. 
There is said to be a "stigma" associated with bankruptcy that supports the deterrence viewpoint. Bankruptcy, IVAs and County Court judgments, so called "black" information, are routinely recorded and included in commercially available Credit Reference databases. A Credit Reference search can highlight a previous bankruptcy or IVA for up to six years beyond the discharge of a Bankruptcy Order or completion of an IVA ${ }^{30}$. Institutional creditors often base their credit-scoring and screening on such databases. The existence of this negative information assumes an importance in decision making despite the fact that such information fails to distinguish between the dishonest and the "unlucky" debtor or the recalcitrant bankrupt and the debtor who works hard to ensure that the IVA succeeds.

Banks' also find themselves in a privileged position in bankruptcy through their taking of direct and indirect security and guarantees - a privilege maintained by the priority given to types of creditor in the Insolvency Act 1986. An unpopular view put forward in 1992 was the outlawing of collateral that would:

“....force banks into relationship banking, rather than simply paying lip service to it in hard times." 31

This view ignores the increased cost of credit that unsecured lending would bring but does address the fundamental relationship between banker and customer.

Creditors' maintenance of a bankruptcy “stigma” is under pressure from government ${ }^{32}$ and society in general. A society based on credit generally has a greater acceptance of debt and a more permissive attitude to default ${ }^{33}$. The sheer numbers of individuals seeking the protection of bankruptcy also serves to diminish its threat of censure ${ }^{34}$. 
Together, the perceived inefficiency in official bankruptcy administration and the automatic discharge from bankruptcy after three years appear a favourable alternative when compared with the five years for the average $\operatorname{IVA}^{35}$.

A more accessible feature of the equation, for UK creditors is the institutional credittrust relationship between lender and borrower. Initial lending relationships between banks and new customers are likely to be deterrence based but will develop into knowledge based relationships where personal contact and repeated interaction are prevalent $^{36}$. Personal lending by UK banks is rarely relationship based, however and most “arms-length” consumer credit transactions will remain deterrence based.

When the value of the deterrence diminishes, however, as society's view changes and as bankruptcy law favours rehabilitation, the deterrent effect breaks down. In addition the deterrence-based relationship is unlikely to engender any emotional or moral input by the borrower.

\section{Conclusions}

This paper presents a dilemma for bankers. It is a common dilemma as short-term profits are often prioritised ahead of long-term gains. It also presents a range of options for the bank when customer default presages formal insolvency.

Traditionally "short termism”, driven by the need to satisfy shareholders, has taken overwhelming precedence over the need to develop long term relationships with 
customers. Increases in the level of competition have, however, focused attention on the importance of customer retention and the active management of the bankercustomer relationship.

Consequently, banks that were traditionally transaction oriented, with an emphasis on standardisation and centralisation, in an endeavour to reduce costs, are emerging as relationship oriented organisations. The value and importance of relationship strategies in reducing moral hazard in the provision of credit to personal customers has been discussed. The paper also recognises the impact of moral hazard on the administration of insolvency law, which, since 1986 has embraced the concepts of rescue and survival.

Insolvency law has, in this respect, been ahead of the "thinking” within banks and, significantly, has reflected the changing ethical attitudes of society to debt. In beginning to emerge as relationship-oriented organisations, therefore, the banks are adopting the values of society and the legal system but still have a long way to go in taking full advantage of IVAs. In a competitive environment banks need to embrace the importance of business rescue and survival in order to benefit from customer retention and continuing relationships with their debtor customers. 
Figure 1: UK Individual Insolvency Growth 1987 - 1999*

( ${ }^{\star} 1999$ estimate based on Q1 and Q2)

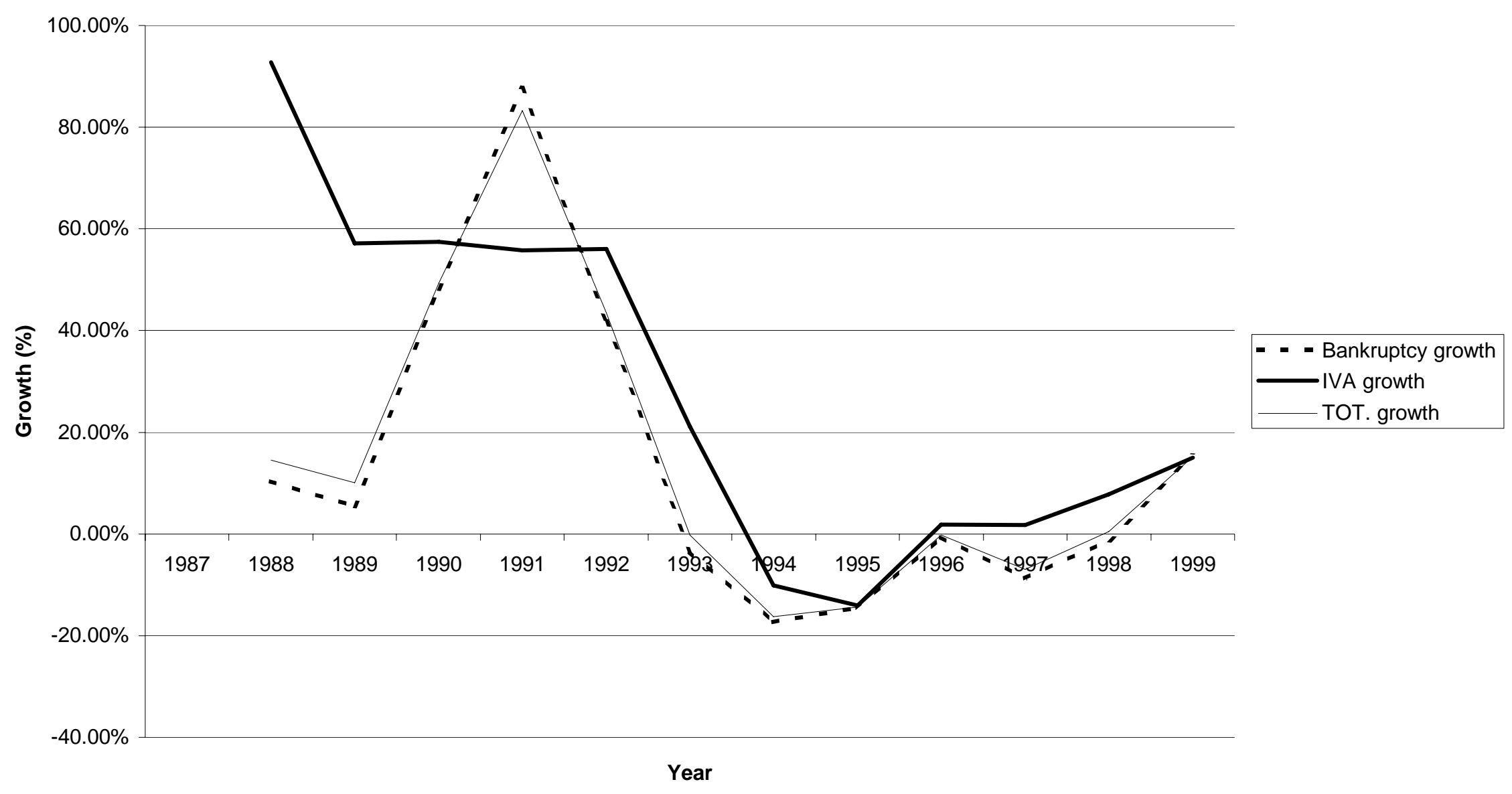

Source DTI 


\section{REFERENCES}

${ }^{1}$ See Arora A (1994), Cases and Materials in Banking Law, Pitman, London.

${ }^{2}$ British Bankers Association, (1998), The Banking Code (1998 Revised Edition), BBA, London.

${ }^{3}$ Pond K, (1999) Implications of the Insolvency Act 1986: Case study of a major UK Bank, Loughborough University Banking Centre Working Paper, forthcoming.

${ }^{4}$ Howcroft JB and Hamilton R, (1999), Perspectives of change in retail banking, Journal of Financial services marketing, Vol4, No.1

${ }^{5}$ Leyshon A \& Thrift N, (1999), Lists come alive: electronic scoring systems of knowledge and the rise of credit-scoring in retail banking, Economy \& Society, Vol. 28, No. 3.

${ }^{6}$ National Consumer Council, (1983), Banking Services and the Consumer, Methuen

${ }^{7}$ Jack Committee, (1989), Report on Banking Services - Law \& Practice, HMSO, Cm.622

${ }^{8}$ Morison IC, (1989), The Jack Report - Secure and Fair, Banking World, Vol 7, No. 7, July.

${ }^{9}$ Howcroft JB and Hamilton R, op. cit.

${ }^{10}$ Stone M, Woodcock N and Wilson M, (1996), Managing the Change from Marketing Planning to Customer Relationship Management, Long range Planning, Vol 29, No. 5

${ }^{11}$ Doherty NF and Pond K, (1995), An Expert system solution to mortgage arrears problems, Service Industries Journal, Vol 15, No.2.

${ }^{12}$ Beckett-Camarata EJ, Camarata MR and Barker RT, (1998), Integrating Internal and External Customer relationships through Relationship Management: A Strategic Response to a Changing Global Environment, Journal of Business Research, Vol 41, Part 1.

${ }^{13}$ Smith JB, (1998), Buyer-Seller relationships: Similarity,Relationship Management and Quality, Psychology and Marketing, Vol 15, No. 1.

${ }^{14}$ Cork Committee, (1982),Insolvency Law \& Practice - Report of the Review Committee, Cmnd. 8558, HMSO, London.

${ }^{15}$ Department of Trade and Industry, (1984), A Revised Framework for Insolvency Law, White Paper, Cmnd. 9175, London. 
${ }^{16}$ Lawson S, (1992), Individual Voluntary Arrangements, Jordans, Bristol.

${ }^{17}$ The Insolvency Service, (1991 - 1998), Insolvency - General Annual report for the years 1990 - 1997, HMSO, London. DTI Statistics Directorate, (1999),

http://www.dti.gov.uk/sd/insolv/view.htm

${ }^{18}$ Pond K, (1998), An insolvent decade: The changing nature of the IVA 1987 - 1997,

Loughborough University Banking Centre Research Paper, Loughborough, 125/98,

October.

19. Society of Practitioners of Insolvency, (1992 to 1998), Personal Insolvency in the

United Kingdom - The First - Seventh SPI surveys, SPI, London.

${ }^{20}$ Pond K, (1998), A decade of change for Individual Voluntary Arrangements,

Insolvency Law \& Practice, Vol 14, No 6, December.

${ }^{21}$ British Bankers Association, (1999), Banking Business - An Abstract of Banking

Statistics, Vol 16.

${ }^{22}$ Lord Chancellors Department, (1992 - 1999), Judicial Statistics for the years 1991 1998, HMSO, Various.

${ }^{23}$ Gladstone B and Lane Lee J, (1995), The Operation of the Insolvency System in the

UK: Some Implications for Entrepreneuralism, Small Business Economics, Vol 7,

Part 1 and Gopinath C, (1995), Bank Strategies towards Firms in Decline, Journal of

Business Venturing, Vol 10, Part 1, 75

${ }^{24}$ Pond K, (1999), op. cit.

${ }^{25}$ Atkinson D, (1999), New deal for bankrupts worries banks, The Guardian, 27

February

${ }^{26}$ Cork Committee, (1982), op.cit.

${ }^{27}$ Ramsay I, (1997), Models of Consumer Bankruptcy: Implications for Research and Policy, Journal of Consumer Policy, Vol 20.

${ }^{28}$ Cork Committee, (1982), op. cit.

${ }^{29}$ Pond K, (1999), op. cit.

${ }^{30}$ Robson P, (1999), Can American-style liquidation mean better business? Credit Management, July.

${ }^{31}$ Harris A, (1992), Financial Times cited in Prindl AR and Prodhan B (Ed.), (1994),

The ACT Guide to Ethical Conflicts in Finance, Blackwells.

${ }^{32}$ Atkinson D, (1999) op. cit. 
${ }^{33}$ Lea S E G, Webley P and Levine R M, (1993), “The economic psychology of consumer debt”, Journal of Economic Psychology, Vol: 14, 85 - 119.

${ }^{34}$ Bien M, (1999), Quick action can keep you out of the bankruptcy court, The Times, 17 April, 64, and Wise L M, (1997), “Oh Bankruptcy, where is thy sting? Oh, creditor, where is thy victory?”, http://www.insolvency.co.uk/news/ar190697.htm ${ }^{35}$ Pond K, (1999), op. cit.

${ }^{36}$ Erfat R, (1998), The moral appeal of personal bankruptcy, Whittier Law Review, Vol. 20, 141-168. 